\title{
Strategi Pemberdayaan Masyarakat Miskin Melalui Pengembangan Kelompok Usaha Bersama (Studi Kasus Pada KUBE Fakir Miskin "Sama Handi' di Kecamatan Kurun, Kabupaten Gunung Mas)
}

\author{
Siska Karunia ${ }^{1, *}$, Jhon Wardie ${ }^{2}$, Eka Nor Taufik ${ }^{2}$ \\ ${ }^{1}$ Alumni Program Studi Magister Pengelolaan Sumberdaya Alam dan Lingkungan Universitas Palangka Raya \\ ${ }^{2}$ Program Studi Magister Pengelolaan Sumberdaya Alam dan Lingkungan Universitas Palangka Raya \\ *Korespondensi: Siska Karunia (Email: siskakarunia16@yahoo.com)
}

\begin{abstract}
This study aims to describe the general description of KUBE management activities 'Sama Handi' in Kurun District, Gunung Mas Regency. It also intends to formulate a strategy for empowering the poor through the development of KUBE 'Sama Handi'. A SWOT analysis was used to describe qualitatively the data obtained through field observations, interviews/discussions, and documentation. The results suggest that the priority strategies for empowering the poor are: (1) Strategy for increasing livestock population, (2) Strategy for strengthening group institution, (3) Strategy for increasing companion's capacity building, (4) Strategy for enhancing breeders' capacity, (5) Strategy to convert waste into organic and biogas fertilizers. Further, to support the development of KUBE 'Sama Handi' as an agribusiness centre for cattle barns, some strategies can be applied, namely (1) improving marketing system and animal management; (2) capital strengthening; (3) integrating animal husbandry area; and (4) development of livestock supporting infrastructure.
\end{abstract}

Keywords

KUBE, strategy, community empowerment, cattle

\section{PENDAHULUAN}

Indonesia kaya akan sumberdaya alam namun miskin akan sumberdaya manusia. Dibalik kekayaan alam Indonesia yang sangat melimpah tersebut, terdapat sebuah permasalahan yang dihadapi, yaitu kemiskinan. Konflik yang harus diselesaikan dalam pengelolaan sumberdaya alam di Indonesia sangat banyak, namun yang menjadi permasalahan yang terbesar adalah soal ekonomi (menyangkut tentang kemiskinan). Banyaknya cadangan dan potensi sumberdaya alam Indonesia yang saat ini gencar dikelola oleh pemerintah ternyata belum membawa dampak maksimal untuk mengurangi kemiskinan dan meningkatkan kesejahteraan masyarakat. Persentase penduduk miskin di Indonesia menurut data BPS Kabupaten Gunung Mas (2019) pada September 2019 sebesar 9,22\% atau sebesar 24,79 juta orang. Garis kemiskinan pada September 2019 tercatat sebesar Rp. 440.538/kapita/bulan dengan komposisi garis kemiskinan makanan sebesar Rp. 324.911 (73,75\%) dan garis kemiskinan bukan makanan sebesar Rp. 115.627 (26,25\%). Penanggulangan dan pengentasan kemiskinan harus dilakukan secara terintegrasi menyeluruh dan berkesinambungan dengan memberikan peluang bagi masyarakat miskin untuk membangun dirinya secara partisipatif. Konsep tersebut memberikan dasar dan sasaran dalam upaya perbaikan kondisi dan taraf hidup masyarakat, membangkitkan partisipasi masyarakat dan penumbuhan kemampuan untuk berkembang secara mandiri dan berkelanjutan melalui kegiatan pemberdayaan masyarakat secara berkelompok yang memiliki berbagai aktivitas positif.

Beberapa program penguatan ekonomi juga dilakukan pemerintah Kabupaten Gunung Mas untuk masyarakat dengan strategi mendorong kemandirian usaha-usaha kelompok masyarakat dalam pengentasan kemiskinan. Ada tiga indikator permasalahan kemiskinan yang menonjol. Pertama, jumlah penduduk miskin yang masih cukup besar. Kedua, ketimpangan kemiskinan antar wilayah, dan terakhir, akses dan kualitas pelayanan dasar penduduk miskin yang masih tertinggal.

Kabupaten Gunung Mas dihuni oleh 137.667 orang (BPS Kabupaten Gunung Mas, 2019). Kabupaten ini memiliki luas wilayah sebesar $10.804 \mathrm{~km}^{2}$ dengan kepadatan penduduk sebesar $11 \mathrm{jiwa} / \mathrm{km}^{2}$. Menurut BPS Kabupaten Gunung Mas (2019), sepanjang tahun 2014- 
2018 persentase kemiskinan cenderung menurun walaupun terkadang terjadi fluktuasi.

Kabupaten Gunung Mas telah melaksanakan program -program pemberdayaan masyarakat dari pemerintah terkait pengentasan kemiskinan. Program pemberdayaan kelompok masyarakat tersebut diantaranya yaitu Kelompok Usaha Bersama Fakir Miskin (KUBE-FM) yang merupakan program dari Kementerian Sosial (Kemensos) Direktorat Penanganan Fakir Miskin. Menurut Kemensos RI (2018) Kelompok Usaha Bersama (KUBE) adalah kelompok warga atau keluarga binaan sosial yang atas bimbingan dan kesadaran bersama, diberi tanggung jawab oleh pemerintah untuk memberdayakan kelompok masyarakat miskin dengan pemberian modal usaha melalui program Bantuan Langsung Pemberdayaan Sosial (BLPS) untuk mengelola Usaha Ekonomi Produktif (UEP). Usaha Ekonomi Produktif (UEP) adalah bantuan sosial yang diberikan kepada KUBE untuk meningkatkan pendapatan dan kesejahteraan sosial keluarga.

Pembentukan KUBE dimaksudkan untuk meningkatkan motivasi, interaksi dan kerjasama kelompok, meningkatkan kemampuan usaha anggota KUBE secara bersama-sama agar dapat memanfaatkan potensi dan sumber daya ekonomi lokal, dapat memperkuat budaya kewirausahaan dan mengembangkan akses pasar serta menjalin kemitraan dengan pihak terkait. KUBE 'Sama Handi' di Kelurahan Tampang Tumbang Anjir Kecamatan Kurun yang menjadi obyek penelitian ini mempunyai kegiatan usaha peternakan sapi. KUBE 'Sama Handi' ini merupakan salah satu dari 95 KUBE yang ada di wilayah Kabupaten Gunung Mas. Masalah-masalah mendasar yang dihadapi dalam pengelolaan KUBE harus dapat ditemukenali dengan baik, untuk memudahkan merumuskan solusinya secara efektif.

Penelitian ini berupaya untuk mengetahui gambaran umum tentang kegiatan KUBE dan merumuskan strategi pemberdayaan masyarakat miskin melalui pengembangan Kelompok Usaha Bersana (KUBE). Hasil akhir dari strategi ini adalah keberlanjutan usaha KUBE yang mendorong kesejahteraan anggota kelompok dan masyarakat dalam upaya pengentasan kemiskinan yang dapat meningkatkan kemampuan dan daya saing masyarakat dalam memanfaatkan potensi diri dan lingkungannya. Dampak yang diharapkan dengan adanya kegiatan pemberdayaan masyarakat secara berkelompok melalui KUBE yaitu meningkatnya motivasi keluarga miskin supaya maju, meningkatkan interaksi dan kerjasama dalam kelompok keluarga miskin, mendayagunakan potensi sumberdaya ekonomi lokal, meningkatkan budaya kewirausahaan, peningkatan pendapatan keluarga dan masyarakat mampu membuka lapangan kerja secara mandiri serta terjaga dan terkelolanya sumberdaya alam dan lingkungan sekitar serta kedepannya dapat menjadi kawasan lumbung ternak sapi. Peneliti berharap hasil penelitian dapat menjadi bahan masukan/ pertimbangan bagi berbagai pihak yang menyelenggarakan program pengentasan kemiskinan pada umumnya dan sebagai bahan kebijakan strategi selanjutnya untuk pemberdayaan KUBE peternakan sapi di lokasi penelitian.

\section{METODOLOGI}

Penelitian ini dilaksanakan di Kelurahan Tampang Tumbang Anjir, Kecamatan Kurun, Kabupaten Gunung Mas. Lokasi ini di pilih karena sebagai KUBE dengan kategori berkembang dibandingkan dengan KUBE lain di wilayah Kabupaten Gunung Mas yang tidak ada perkembangan (stagnan) dan sebagai salah satu KUBE percontohan untuk pengembangan usaha ternak sapi di Kabupaten Gunung Mas, akan tetapi masih memerlukan pendampingan atau pembinaan.

Data diperoleh dari informan (narasumber) dan responden. Menurut Prastowo (2011) informan merupakan orang yang diperkirakan menguasai dan memahami data, informasi ataupun fakta dari suatu objek penelitian. Informan penelitian ini adalah para pelaku program KUBE. Responden adalah orang yang memberi tanggapan atau reaksi dari suatu masalah. Pemilihan informan dan responden dilakukan secara purposive sampling yaitu berdasarkan penilaian peneliti akan pengetahuan calon responden dan informan untuk menjawab pertanyaan terkait penelitian yang dilakukan dan yang memiliki pengalaman atau memiliki pengetahuan terkait fokus penelitian. Jumlah sampel dalam penelitian ini disajikan pada Tabel 1 .

Tabel 1. Distribusi pekerjaan informan dan responden

\begin{tabular}{clr}
\hline No. & \multicolumn{1}{c}{ Uraian } & Jumlah \\
\hline 1. & Dinas Sosial Kabupaten Gunung Mas & 3 orang \\
2. & Kelurahan Tampang Tumbang Anjir & 2 orang \\
3. & Tenaga Kerja Sosial Kecamatan (TKSK) & 1 orang \\
4. & Pengurus dan anggota KUBE Sama Handi & 10 orang \\
5. & Warga dan tokoh masyarakat & 19 orang \\
\hline & Total & 35 orang
\end{tabular}

Data yang dipergunakan dalam penelitian ini yaitu dikumpulkan dari berbagai sumber, data tersebut berupa data primer yang diperoleh melalui diskusi/wawancara langsung dengan tokoh formal maupun informal, diskusi kelompok dan pengamatan lapangan (observasi). Kemudian pengumpulan data sekunder berupa data stastistik, data laporan dari instansi-intstansi, kajian/ penelitian pihak lain dan publikasi lainnya. Tahapan dan pendekatan yang dilakukan dalam pengumpulan data adalah:

1. Observasi, yaitu pengamatan secara langsung atau peninjauan secara visual langsung di lapangan atau di lokasi penelitian dengan objek KUBE di Kelurahan Tampang Tumbang Anjir. Observasi dilakukan terhadap subjek, perilaku subjek selama wawancara, interaksi subjek dengan peneliti dan hal-hal yang dianggap relevan sehingga dapat memberikan data 
tambahan terhadap hasil wawancara. Teknik observasi ini digunakan peneliti untuk melihat serta mengamati situasi dan kondisi di lapangan (Afifudin dan Saebani, 2012).

2. Diskusi dan wawancara mendalam (in-depth inteviews) yang dilakukan peneliti untuk menggali informasi dari unsur pemerintah (Dinas Sosial Kabupaten Gunung Mas), aparat kelurahan, pengurus dan anggota KUBE "Sama Handi" serta tokoh-tokoh masyarakat. Dalam teknik wawancara peneliti menggunakan alat bantu berupa catatan lapangan dan kuesioner.

3. Kuesioner atau angket merupakan teknik pengumpulan data dengan cara memberi seperangkat pertanyaan atau pernyataan tertulis kepada responden/ informan untuk dijawab. Kuesioner diberikan kepada responden untuk memperoleh data tentang kekuatan, kelemahan, peluang dan ancaman yang dimiliki dan dihadapi oleh KUBE "Sama Handi" Kelurahan Tampang Tumbang Anjir di Kecamatan Kurun.

4. Dokumentasi adalah suatu teknik pengumpulan data dengan cara mempelajari dokumen untuk mendapatkan data dan informasi yang berhubungan dengan masalah yang diteliti seperti data-data dan dokumen, produk hukum/ kebijakan pemerintah dalam penanggulangan kemiskinan, bahan-bahan laporan pelaksanaan KUBE, buku jurnal dan arsip lain yang relevan dengan pelaksanaan penelitian.

Metode yang digunakan dalam penelitian ini adalah metode deskriptif dengan pendekatan kualitatif. Metode analisis deskriptif kualitatif digunakan untuk menjawab tujuan penelitian yang pertama, yaitu untuk mengetahui gambaran umum kegiatan pemberdayaan Kelompok Usaha Bersama "Sama Handi" yang ada di Kelurahan Tampang Tumbang Anjir, Kecamatan Kurun Kabupaten Gunung Mas. Sedangkan analisis data yang kedua menggunakan analisis faktor internal atau Internal Strategic Factors Analiysis Summary (IFAS), analisis faktor eksternal atau External Strategic Factors Analiysis Summary (EFAS) serta metode analisis SWOT untuk menjawab tujuan yang kedua tentang rumusan strategi pemberdayaan masyarakat miskin melalui pengembangan KUBE "Sama Handi" di Kecamatan Kurun Kabupaten Gunung Mas. Analisis SWOT digambarkan dalam matrik SWOT dengan 4 kemungkinan alternatif strategi, yaitu strategi kekuatan-peluang (SO strategies), strategi kelemahan-peluang (WO strategies), strategi kekuatan-ancaman (ST strategies), dan strategi kelemahan-ancaman (WT strategies).

Beberapa penelitian tentang pemberdayaan masyarakat miskin telah banyak dilakukan. Namun demikian penelitian yang dilakukan ini tidak akan terlepas dan mungkin saja mengacu kepada sumbersumber dan literatur-literatur yang sama atau hampir sama dengan penelitian sebelumnya, sehingga penelitian yang dilakukan ini diharapkan dapat lebih melengkapi.

\section{HASIL}

Kelompok Usaha Bersama (KUBE) 'Sama Handi' beralamatkan di Jalan Damang Sawang No. 02 RT. 3/ RW. 01 Kelurahan Tampang Tumbang Anjir, Kecamatan Kurun Kabupaten Gunung Mas. Nama kelompok 'Sama Handi' berarti sesama keluarga. Jadi keanggotaan kelompok ini rata-rata masih ada dalam satu hubungan keluarga.

Poses pembentukan Kelompok Usaha Bersama (KUBE) di Kelurahan Tampang Tumbang Anjir Kecamatan Kurun difasilitasi oleh Dinas Sosial Kabupaten Gunung Mas pada tahun 2011, dengan tahap pelaksanaan dilakukan setelah proses perencanaan selesai dan telah ada keputusan pengalokasian dana kegiatan. Pelaksanaan kegiatan meliputi tahap persiapan pembentukan kelompok, penentuan jenis usaha, sosialisasi pelatihan dan bimbingan motivasi. Setelah terimplementasi maka dilakukan proses evaluasi monitoring dan pelaporan. Metode yang dijalankan oleh pelaku pemberdayaan dalam hal ini Dinas Sosial Kabupaten Gunung Mas adalah penyokongan, perlindungan dan pemeliharaan sementara untuk pemungkinan dan penguatan diserahkan sepenuhnya kepada pendamping lapangan Tenaga Kerja Sosial Kecamatan (TKSK). Kelompok Usaha Bersama (KUBE) 'Sama Handi' dibentuk sebagai upaya pengentasan kemiskinan anggotanya. Keluarga miskin tersebut sebelum menjadi anggota KUBE 'Sama Handi', pada umumnya mempunyai pekerjaan yang tidak tetap, seperti menjadi buruh bangunan, buruh harian lepas pada perusahaan kayu, petani karet, petani sawit, penambang pasir dan emas skala kecil serta sebagian besar bekerja apa adanya saja dan tanpa adanya keahlian khusus dalam bekerja. Hal ini terjadi disebabkan SDM keluarga miskin tersebut (khususnya kepala keluarga) umumnya rendah. Anggota KUBE 'Sama Handi' berjumlah 10 orang, berasal dari warga Kelurahan Tampang Tumbang Anjir dengan tingkat pendidikan paling tinggi tamatan SMA. Faktor pendidikan sangat berpengaruh terhadap pengelolaan usaha. Mereka memiliki keterbatasan dalam akses informasi tentang manajemen usaha, keterbatasan dalam akses permodalan ke lembaga keuangan.

Kegiatan KUBE 'Sama Handi' di awali pertama kali oleh masyarakat Kelurahan Tampang Tumbang Anjir dengan membentuk kelompok yang memiliki ternak sapi lalu membuat proposal ke Dinas Sosial Kabupaten Gunung Mas. Selanjutnya proposal tersebut diterima oleh pemerintah dan disetujui penunjukan dan penetapannya oleh Kepala Dinas Sosial Provinsi Kalimantan Tengah melalui Surat Keputusan dengan nomor SK. 467.3/1335/DINSOS.III/2011 pada tanggal 14 Oktober 2011, perihal Penunjukan dan Penetapan NamaNama Penerima Bantuan Kelompok Usaha Bersama (KUBE) Penumbuhan Fakir Miskin Kegiatan Penanggulangan Kemiskinan Perkotaan Kalimantan Tengah Tahun 2011. Kegiatan usaha ekonomi produktif dilakukan dengan memberikan modal usaha yang 
diberikan kepada KUBE sebanyak Rp. 20.000.000. Modal usaha tersebut berdasarkan hasil rapat anggota KUBE disepakati untuk membeli bibit ternak sapi sebanyak 3 (tiga) ekor sapi betina dan pembelian vitamin, obat cacing serta makanan ternak. Pada tahap ini ditandai dengan anggota kelompok sudah mulai mengetahui tujuan mereka dalam berkelompok. Pertemuanpertemuan kelompok juga rutin dilaksanakan walaupun tingkat kehadiran anggota kelompok dalam setiap pertemuan kelompok masih terbilang rendah, akan tetapi informasi mengenai perkembangan kelompok selalu diinformasikan kepada seluruh anggota oleh anggota kelompok yang hadir pada pertemuan kelompok, sehingga secara teknis pelaksanaan kegiatan usaha hampir tidak pernah menemukan permasalahan yang berarti.

Dalam perkembangannya, di tahun 2014 menghasilkan tambahan 3 ekor sapi (1 jantan dan 2 betina). Tahun 2015 menghasilkan (3 ekor sapi jantan), dari 3 ekor sapi jantan ini dijual 1 ekor dan diganti 1 ekor sapi betina. Tahun 2016 menghasilkan 4 ekor sapi jantan lagi sehingga pada tahun 2017 ada 2 ekor sapi jantan dan ada 4 ekor sapi betina jadi jumlah pada tahun 2017 sebanyak 6 ekor sapi. Pada tahun 2018 jumlah sapi ada 6 ( 1 jantan dan 5 betina) dan kemudian mendapat bantuan sapi lagi sejumlah 5 ekor (4 ekor sapi betina dan 1 ekor sapi jantan) dari Dinas Sosial Kabupaten Gunung Mas sehingga sekarang jumlah ternak sapi pada KUBE 'Sama Handi' sebanyak 11 ekor sapi.. Hasil dari ternak sapi ini anggota dan pengurus KUBE bersepakat membeli sebidang tanah dengan harga Rp. 15.000.000 ukuran seluas 1 (satu) hektar yang digunakan untuk lapangan gembala ternak sapi. Setelah KUBE 'Sama Handi' dianggap mandiri serta pendampingan tidak dilakukan lagi, terjadi kemunduran aktivitas kegiatan KUBE 'Sama Handi'. Kemunduran aktivitas ini disebabkan kurangnya kekompakan dan pertemuan kelompok. Sosialisasi program dirasakan masih kurang, sehingga materi sosialisasi kurang dipahami secara tepat oleh anggota KUBE maupun tenaga pendamping lokal. Pendamping belum optimal melaksanakan tugasnya karena kompetensinya masih relatif rendah terkait pengetahuan dan keterampilan sosial dalam pendampingan.

Kegiatan KUBE 'Sama Handi' yaitu usaha penggemukan sapi dengan pengelolaan bersifat individu dan kelompok, namun pembinaan tetap dalam kelompok yang saling bekerja sama bergotong-royong. Jenis sapi yang diternak adalah sapi Bali. Jenis sapi Bali ini mudah perawatannya, mudah beradaptasi dengan lingkungan, daging lebih banyak dan harga terjangkau. Pengalaman anggota KUBE dalam pengelolaan beternak sapi cukup memadai walaupun dipelajari secara otodidak. Lokasi penggembalaan ternak berada pada lahan bekas penembangan emas dan pasir. Kondisi tempat penggembalaan sapi tidak mengganggu ketertiban dan kepentingan umum setempat dan tidak bertentangan dengan tata ruang wilayah. Lokasinya strategis dekat dengan ibukota kabupaten, tempatnya mudah dijangkau alat transportasi dan sudah ada jaringan listrik PLN. Sumber pengairan lahan peternakan berasal dari Sungai Kahayan. Ternak sapi belum ada kandang, sapi tersebut masih dilepas kelapangan rumput seluas 4 hektar dengan pembatas pagar kayu dan kawat besi.

KUBE 'Sama Handi' di Kecamatan Kurun belum melakukan pengolahan limbah ternak sapi yang dapat dimanfaatkan sebagai bahan pupuk organik kompos dan biogas serta belum memanfaatkan lahan bekas tambang untuk budidaya tanaman hijauan pakan ternak. Sapi bakalan diperoleh dari daerah luar Kabupaten Gunung Mas. Kendala yang dihadapi di Kecamatan Kurun Kabupaten Gunung Mas belum terbangun sarana prasarana pendukung peternakan seperti Rumah Potong Hewan (RPH), Pasar Hewan, Pusat Kesehatan Hewan (Puskeswan) dan Pos Inseminasi Buatan (Pos IB), transaksi jual beli belum berdasarkan penimbangan bobot badan (masih menggunakan taksiran) dan masih terpengaruh adanya pengepul sapi (blantik).

Pemeliharaan sapi yang dikerjakan KUBE 'Sama Handi' masih tradisional, belum banyak mendapat sentuhan teknologi, pengelolaan sederhana dan kurang berwawasan agribisnis. Usaha budidaya ternak sapi bukan sebagai sumber pekerjaan yang utama, masih merupakan usaha sambilan. Pola pengembangan peternakan sapi yang dilakukan umumnya masih tradisional bersifat usaha peternakan rakyat, dimana saatsaat tertentu ketika peternak memerlukan uang dalam memenuhi kebutuhan yang mendesak maka ternak sapi tersebut dapat dijual.

Untuk melihat kemungkinan pengembangan konsep pemberdayaan KUBE 'Sama Handi' di masa yang akan datang, peneliti mencoba menganalisis data dengan metode analisis SWOT yang bertujuan untuk mengetahui kekuatan KUBE yang dapat dikembangkan, kelemahan yang harus diperbaiki, peluang yang dapat menjadikan KUBE lebih berhasil, dan ancaman yang mungkin terjadi. Dari hasil survei pengamatan dilapangan dan wawancara yang mendalam (indepth interview) dengan menggunakan kuesioner yang sudah di uji validitas dan reliabilitasnya, diperoleh 36 faktor pernyataan kuesioner yang sudah diidentifikasi dan direspon oleh 35 orang responden. Faktor-faktor yang telah teridentifikasi tersebut selanjutnya dievaluasi menggunakan matriks Internal Factors Analysis Summary (IFAS) dan matriks External Factors Analysis Summary (EFAS) untuk menentukan nilai bobot, rating dan skornya, kemudian di analisa menggunakan metode SWOT untuk memperoleh beberapa rumusan strategis baik internal maupun eksternal. Rumusan strategi internal meliputi faktor kekuatan dan kelemahan sedangkan rumusan strategi eksternal meliputi faktor peluang dan ancaman. Hasil analisis matrik IFAS untuk faktor kekuatan dan kelemahan internal serta hasil analisis matrik EFAS untuk faktor peluang dan ancaman eksternal dapat dilihat pada Tabel 2, Tabel 3, Tabel 4 dan Tabel 5. 
Tabel 2. Hasil Analisis Matriks IFAS Kekuatan (strengths)

\begin{tabular}{|c|c|c|c|c|c|}
\hline No. & Faktor Kekuatan Internal & Jumlah & Bobot & Rating & Skor \\
\hline 1. & Dukungan/ bantuan pemerintah & 153 & 0,138 & 4,37 & 0,60 \\
\hline 2. & Ketersediaan lahan peternakan luas & 146 & 0,132 & 4,17 & 0,55 \\
\hline 3. & Interaksi antar anggota masih bersifat kekeluargaan & 105 & 0,095 & 3,00 & 0,28 \\
\hline 4. & Jenis Sapi Bali cocok dengan kondisi alam & 143 & 0,129 & 4,09 & 0,53 \\
\hline 5. & Lahan beternak sapi milik sendiri & 145 & 0,131 & 4,14 & 0,54 \\
\hline 6 & SDA yang menunjang untuk pengembangan ternak & 139 & 0,125 & 3,97 & 0,50 \\
\hline 7. & Dukungan kelembagaan & 136 & 0,123 & 3,89 & 0,48 \\
\hline \multirow[t]{2}{*}{8.} & Akses strategis lokasi mudah dijangkau & 143 & 0,129 & 4,09 & 0,53 \\
\hline & Rerata & 1110 & 1,00 & & 4,00 \\
\hline
\end{tabular}

Tabel 3. Hasil analisis matriks IFAS Kelemahan (weaknesses)

\begin{tabular}{clcccc}
\hline No. & Faktor Kelemahan Internal & Jumlah & Bobot & Rating & Skor \\
\hline 1. & Tenaga pendamping KUBE yang berkompeten masih terbatas & 152 & 0,119 & 4,34 & $\mathbf{0 , 5 2}$ \\
2. & Minimnya sumber hijauan pakan ternak & 141 & 0,111 & 4,03 & 0,45 \\
3. & Pemasaran hasil produksi belum maksimal & 107 & 0,084 & 3,06 & 0,26 \\
4. & Pendidikan peternak masih rendah & 132 & 0,104 & 3,77 & 0,39 \\
5. & Keterbatasan modal usaha ternak & 142 & 0,112 & 4,06 & 0,45 \\
6. & Pola pemeliharan ternak masih tradisional & 130 & 0,102 & 3,71 & 0,38 \\
7. & Usaha ternak sebagai sambilan & 137 & 0,108 & 3,91 & 0,42 \\
8. & Usaha ternak kurang berkembang & 119 & 0,094 & 3,40 & 0,32 \\
9. & Minimnya sarana prasarana pendukung peternakan & 88 & 0,069 & 2,51 & 0,17 \\
10. & Belum adanya pemanfaatan pengolahan limbah kotoran sapi & 124 & 0,097 & 3,54 & 0,35 \\
\hline \multicolumn{7}{c}{ Rerata } & $\mathbf{1 2 7 2}$ & $\mathbf{1 , 0 0}$ & & $\mathbf{3 , 7 1}$ \\
\hline
\end{tabular}

Tabel 4. Hasil analisis matriks EFAS Peluang (opportunities)

\begin{tabular}{clcccc}
\hline No. & \multicolumn{1}{c}{ Faktor Peluang Eksternal } & Rerata & Bobot & Rating & Skor \\
\hline 1. & Kebijakan pemerintah membatasi impor daging sapi & 158 & 0,103 & 4,51 & 0,46 \\
2. & Perkembangan teknologi pengolahan pakan & 136 & 0,089 & 3,89 & 0,34 \\
3. & Kesempatan kerja dibidang peternakan & 150 & 0,098 & 4,29 & 0,42 \\
4. & Pengolahan limbah ternak jadi biogas dan pupuk organik & 160 & 0,104 & 4,57 & $\mathbf{0 , 4 8}$ \\
5. & Kemudahan perijinan usaha & 140 & 0,091 & 4,00 & 0,36 \\
6. & Program pengembangan peternakan sapi & 121 & 0,079 & 3,46 & 0,27 \\
7. & Produk olahan dari daging sapi terus berkembang & 152 & 0,099 & 4,34 & 0,43 \\
8. & Perkembangan IPTEK bidang peternakan & 86 & 0,056 & 2,46 & 0,14 \\
9. & Permintaan dan harga daging sapi makin tinggi & 153 & 0,100 & 4,37 & 0,44 \\
10. & Perkembangan teknologi kawin suntik (IB) ternak sapi & 131 & 0,085 & 3,74 & 0,32 \\
11. & Pasokan kebutuhan bibit sapi sangat menjanjikan & 149 & 0,097 & 4,26 & 0,41 \\
\hline \multicolumn{2}{r}{ Rerata } & $\mathbf{1 5 3 6}$ & $\mathbf{1 , 0 0}$ & \multicolumn{4}{c}{$\mathbf{0 8}$} \\
\hline
\end{tabular}

Tabel 5. Hasil analisis matriks EFAS Ancaman (threats)

\begin{tabular}{clcccc}
\hline No. & Faktor Ancaman Eksternal & Rerata & Bobot & Rating & Skor \\
\hline 1. & Persaingan usaha dengan peternak sapi lainnya & 134 & 0,154 & 3,83 & 0,59 \\
2. & Pengaruh iklim lingkungan & 135 & 0,155 & 3,86 & 0,60 \\
3. & Alih fungsi lahan peternakan & 127 & 0,146 & 3,63 & 0,53 \\
4. & Lahan peternakan sapi bekas tambang emas dan pasir & 139 & 0,159 & 3,97 & $\mathbf{0 , 6 3}$ \\
5. & Penolakan dari masyarakat (bau limbah) & 103 & 0,118 & 2,94 & 0,35 \\
6. & Penyakit infeksi flu sapi yang membahayakan kesehatan & 119 & 0,136 & 3,40 & 0,46 \\
7. & Peran blantik sapi yang dominan penentuan harga & 115 & 0,132 & 3,29 & 0,43 \\
\hline \multicolumn{2}{r}{ Rerata } & $\mathbf{8 7 2}$ & $\mathbf{1 , 0 0}$ & & $\mathbf{3 , 5 9}$ \\
\hline
\end{tabular}




\section{PEMBAHASAN}

Berdasarkan hasil analisis matrik IFAS dan EFAS diperoleh nilai total skor tertimbang untuk keseluruhan faktor lingkungan internal dan faktor lingkungan eksternal. Hasil analisis ini dapat dipergunakan untuk merumuskan strategi pemberdayaan masyarakat miskin pada KUBE 'Sama Handi' di lokasi penelitian dengan memadukan faktor internal dan eksternal, nilai total skor kekuatan dikurangi dengan nilai total skor kelemahan, kemudian nilai total skor peluang dikurangi nilai total skor ancaman. Untuk lebih jelasnya hasil skoring dapat dilihat pada Tabel 6.

Tabel 6. Hasil skoring faktor internal dan faktor eksternal

\begin{tabular}{lcc}
\hline \multicolumn{1}{c}{ Kriteria } & Total Skor & Nilai Koordinat \\
\hline $\begin{array}{l}\text { Faktor Internal } \\
\text { Kekuatan (strengths) }\end{array}$ & 4,00 & $\mathbf{0 , 2 9}$ \\
$\begin{array}{l}\text { Kelemahan } \\
\quad \text { (weaknesses) }\end{array}$ & 3,71 & \\
$\begin{array}{l}\text { Faktor Eksternal } \\
\text { Peluang }\end{array}$ & & \\
$\quad$ (opportunities) & 4.08 & $\mathbf{0 . 4 9}$ \\
Ancaman (threats) & 3,59 & \\
\hline
\end{tabular}

Keterangan:

Nilai faktor internal $=($ skor kekuatan $)-($ skor kelemahan $)$

$$
\begin{aligned}
& =(4,00)-(3,71) \\
& =0,29
\end{aligned}
$$

Nilai faktor eksternal $=($ skor peluang $)-($ skor ancaman $)$

$$
\begin{aligned}
& =(4,08)-(3,59) \\
& =0,49
\end{aligned}
$$

Berdasarkan Tabel 6 diketahui secara internal menunjukkan pengaruh kekuatan lebih besar dibandingkan pengaruh kelemahan pada pengelolaan KUBE 'Sama Handi'. Dan untuk selisih faktor eksternal (peluang-ancaman) sebesar 0,49 menunjukkan pengaruh peluang lebih besar dibandingkan pengaruh ancaman

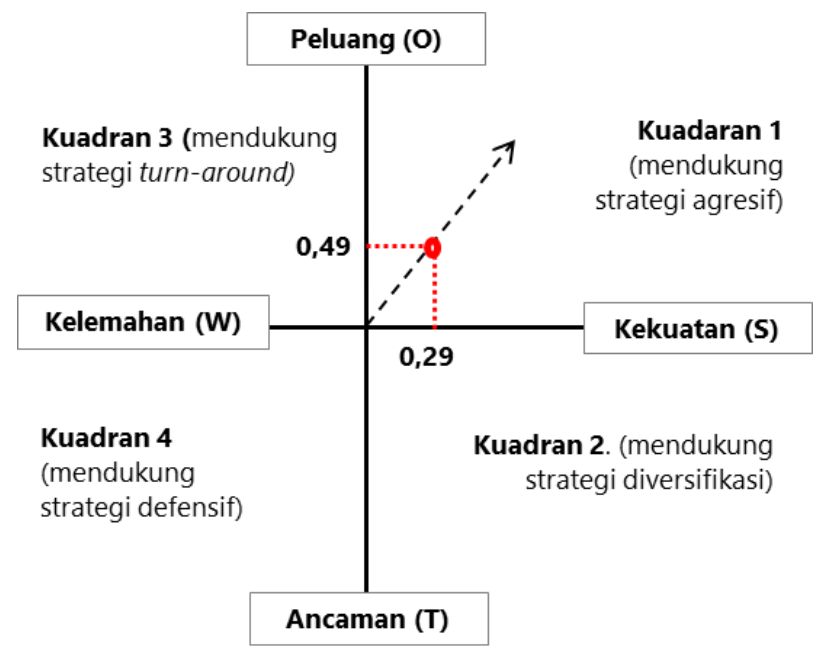

Gambar 1. Posisi kuadran dalam diagram SWOT pada pengelolaan KUBE 'Sama Handi'. Selanjutnya hasil penghitungan tersebut digunakan sebagai nilai titik koordinat untuk menentukan posisi kuadran pada diagram SWOT. Posisi kuadran KUBE 'Sama Handi' di Kecamatan Kurun dalam diagram SWOT disajikan pada Gambar 1.

Berdasarkan Gambar 1 dapat diketahui posisi KUBE 'Sama Handi' dalam diagram SWOT berada pada kuadran I yaitu mendukung kebijakan pertumbuhan yang agresif (growth oriented strategy). Strategi agresif merupakan strategi prioritas yang fokus pada Strategi SO (strengths -opportunities) yaitu menggunakan kekuatan yang dimiliki kelompok untuk memanfaatkan peluang yang ada. (Tabel 7). Untuk mendukung pengembangan KUBE 'Sama Handi' sebagai kawasan agribisnis sentra lumbung ternak sapi dapat diterapkan rumusan alternatif strategi ST (Strengths-Threats), strategi WO (WeaknessesOpportunities) dan strategi WT (Weaknesses-Threats).

Prioritas strategi SO yang dapat diterapkan pada KUBE 'Sama Handi' pada saat ini yaitu:

1) Peningkatan Populasi Ternak, melalui pola inti plasma dengan mengintegrasikan usaha kecil/peternak dengan pengusaha besar/investor (pemodal). Turut serta program Upaya Khusus Indukan Sapi/kerbau Wajib Bunting (UPSUS SIWAB) yang digagas Kementerian Pertanian RI.

2) Penguatan Kelembagaan Kelompok dengan menetapkan standar prosedur kelembagaan, pengembangan pusat pelayanan data informasi serta kerjasama dengan semua mitra terkait dari pemerintah, perguruan tinggi, swasta, LSM lingkungan dan lembaga keuangan.

3) Peningkatan Kapasitas Pendamping KUBE melalui bimbingan teknis ketrampilan budi daya ternak, teknis penjualan/ pemasaran ternak sesuai dengan perkembangan ilmu pengetahuan dan teknologi, sehingga pendaping KUBE dapat berinovasi dan mampu mendorong kemandirian KUBE.

4) Peningkatan Kapasitas Peternak melalui kegiatan sosialisasi dan pelatihan pengenalan teknologi baru budidaya ternak sapi terutama Teknologi Pakan, Pembibitan, Kesehatan Hewan, Manajemen Pemeliharaan, Pemasaran dan Pendanaan Peternakan yang disesuaikan dengan kondisi sumberdaya alam dan lingkungan.

5) Pengelolaan Limbah menjadi Pupuk Organik dan Biogas dengan mengintegrasikan tanaman perkebunan dengan ternak sapi dengan memanfaatkan limbah perkebunan sawit untuk pakan ternak dan limbah kotoran sapi diolah sebagai pupuk organik. Kemudian membuat program kompor biogas dengan mengolah limbah kotoran ternak menjadi biogas untuk menghasilkan energi tabarukan dalam bentuk listrik dan gas. Kotoran sapi ini diubah menjadi gas yang bernilai ekonomis. 
Tabel 7. Hasil Analisis Matriks SWOT

\begin{tabular}{|c|c|c|}
\hline & Strength (S) Kekuatan & Weakness (W) Kelemahan \\
\hline $\begin{array}{l}\text { EFAS } \\
\text { Faktor Eksternal }\end{array}$ & $\begin{array}{l}\text { 1. Dukungan/bantuan pemerintah. } \\
\text { 2. Ketersediaan lahan luas. } \\
\text { 3. Interaksi antar anggota bersifat } \\
\text { kekeluargaan. } \\
\text { 4. Jenis Sapi Bali cocok dengan } \\
\text { kondisi alam. } \\
\text { 5. Lahan ternak milik sendiri } \\
\text { 6. Sumberdaya alam yang menunjang. } \\
\text { 7. Dukungan kelembagaan. } \\
\text { 8. Akses strategis lokasi mudah } \\
\text { dijangkau. }\end{array}$ & $\begin{array}{l}\text { 9. Pendamping berkompeten masih } \\
\text { terbatas. } \\
\text { 10. Minimnya sumber pakan ternak. } \\
\text { 11. Pemasaran hasil produksi belum } \\
\text { maksimal. } \\
\text { 12. Pendidikan masih rendah. } \\
\text { 13. Keterbatasan modal usaha. } \\
\text { 14. Pemeliharan tradisional. } \\
\text { 15. Usaha ternak sebagai sambilan. } \\
\text { 16. Usaha ternak kurang berkembang. } \\
\text { 17. Minimnya sarana prasarana pendukung } \\
\text { peternakan. } \\
\text { 18. Belum memanfaatkan pengolahan } \\
\text { limbah. }\end{array}$ \\
\hline Opportunities (O) Peluang & Strategi - SO & Strategi - WO \\
\hline $\begin{array}{l}\text { 1. Kebijakan pemerintah membatasi } \\
\text { impor daging sapi. } \\
\text { 2. Perkembangan teknologi } \\
\text { pengolahan pakan ternak. } \\
\text { 3. Kesempatan kerja peternakan. } \\
\text { 4. Permintaan dan harga daging sapi } \\
\text { meningkat. } \\
\text { 5. Kemudahan perijinan usaha. } \\
\text { 6. Program pengembangan ternak sapi. } \\
\text { 7. Pengolahan limbah kotoran ternak } \\
\text { jadi biogas dan pupuk organik. } \\
\text { 8. Perkembangan IPTEK bidang } \\
\text { 9. Peternakan. } \\
\text { Produk olahan dari daging sapi terus } \\
\text { 10. Perkembang. } \\
\text { suntik (IB) ternak. } \\
\text { 11. Pasokan kebutuhan bibit sapi sangat } \\
\text { menjanjikan. }\end{array}$ & $\begin{array}{l}\text { 1. Strategi Peningkatan Populasi } \\
\text { Ternak. } \\
\text { 2. Strategi Penguatan Kelembagaan } \\
\text { Kelompok. } \\
\text { 3. Strategi Peningkatan Kapasitas } \\
\text { Pendamping/Penyuluh. } \\
\text { 4. Strategi Peningkatan Kapasitas } \\
\text { Peternak. } \\
\text { 5. Strategi Pengolahan Limbah } \\
\text { Menjadi Pupuk Organik dan Biogas. }\end{array}$ & $\begin{array}{l}\text { 1. Strategi Perbaikan Sistem Pemasaran } \\
\text { dan Tata Kelola Ternak. } \\
\text { 2. Strategi Penguatan Permodalan. }\end{array}$ \\
\hline Threats (T) Ancaman & Strategi - ST & Strategi - WT \\
\hline $\begin{array}{l}\text { 1. Persaingan usaha dengan peternak } \\
\text { sapi lainnya. } \\
\text { 2. Pengaruh iklim lingkungan. } \\
\text { 3. Alih fungsi lahan peternakan. } \\
\text { 4. Lahan peternakan sapi bekas } \\
\text { tambang emas dan pasir. } \\
\text { 5. Penolakan dari masyarakat (bau } \\
\text { limbah). } \\
\text { 6. Penyakit infeksi flu sapi yang } \\
\text { membahayakan kesehatan } \\
\text { 7. Peran blantik sapi yang dominan } \\
\text { penentuan harga. }\end{array}$ & $\begin{array}{l}\text { 1. Penerapan Kawasan Peternakan } \\
\text { Terpadu (cluster) }\end{array}$ & $\begin{array}{l}\text { 1. Strategi Pembangunan Sarana Prasarana } \\
\text { Pendukung Peternakan }\end{array}$ \\
\hline
\end{tabular}

Secara garis besar Strategi SO ini mengutamakan pada pengembangan kualitas sumber daya peternak yang berorientasi agribisnis, optimalisasi pemanfaatan dan perlindungan sumber daya alam, pengembangan kelembagaan peternak dan kemitraan dan pengembangan wilayah berdasarkan ternak unggulan.

\section{KESIMPULAN DAN SARAN}

Penelitian ini menghasilkan dua kesimpulan. Pertama, kelompok Usaha Bersama (KUBE) 'Sama Handi' di Kecamatan Kurun kegiatan usahanya adalah peternakan sapi yang merupakan binaan Dinas Sosial
Kabupaten Gunung Mas pada tahun 2011 melalui Program pengembangan Usaha Ekonomi Produktif Fakir Miskin. Kegiatan kelompok masih aktif dan berkembang memberikan manfaat bagi pemberdayaan masyarakat miskin. Sumberdaya alam dan sumberdaya manusia berpotensi untuk dikembangkan. Kondisi lahan bekas penambangan emas dan pasir skala kecil. Letaknya strategis dekat ibukota kabupaten mudah dijangkau alat transportasi dan sudah ada jaringan listrik. Kedepannya lokasi ini apabila dikelola dan ditata dengan baik berpotensi dapat dikembangkan sebagai kawasan agribisnis sentra lumbung peternakan sapi. Pengembangan usaha ternak sapi saat ini menghadapi tantangan, antara lain yaitu aspek pengolahan sumberdaya alam belum optimal, alih fungsi lahan 
(konversi lahan) pertanian ke non pertanian, lahan penggembalaan sapi bekas penambangan emas dan pasir, mutu sumberdaya manusia masih rendah, produktivitas juga masih rendah, bibit mutu rendah, biaya pakan tinggi, skala pemilikan kecil, sistem pemeliharaan ternak masih tradisional, masih sebagai usaha sampingan, manajemen belum efektif, harga sapi yang lebih banyak ditentukan oleh tengkulak (blantik), kapasitas kelompok dan jaringan kerja yang sangat terbatas, keterbatasan modal usaha serta kerjasama lintas sektoral belum terpadu dan belum banyak mendapat sentuhan teknologi.

Kedua, strategi pemberdayaan KUBE "Sama Handi" dari hasil analisis SWOT menunjukkan selisih faktor strategi internal (kekuatan-kelemahan) adalah sebesar 0,29 yang artinya pengaruh kekuatan lebih besar daripada pengaruh kelemahan pada KUBE 'Sama Handi' dan untuk selisih faktor strategi eksternal (peluangancaman) sebesar 0,49 yang artinya pengaruh peluang lebih besar daripada pengaruh ancaman. Posisi KUBE 'Sama Handi' tersebut berada di kuadran I. Strategi prioritas pemberdayaan yang dapat diterapkan pada KUBE 'Sama Handi' saat ini yaitu mendukung kebijakan pertumbuhan yang agresif (growthoriented strategy). Strategi agresif merupakan prioritas strategi yang fokus pada Strategi SO (strengths-opportunities) yaitu menggunakan kekuatan yang dimiliki kelompok untuk memanfaatkan peluang yang ada terdiri dari (1) strategi peningkatan populasi ternak; (2) strategi penguatan kelembagaan kelompok; (3) strategi peningkatan kapasitas pendamping/penyuluh; (4) strategi peningkatan kapasitas peternak; dan (5) strategi pengolahan limbah menjadi pupuk organik dan biogas. Untuk lebih mendukung pengembangan KUBE 'Sama Handi' sebagai kawasan agribisnis sentra lumbung ternak sapi dapat diterapkan rumusan alternatif strategi WO, ST dan WT, yaitu (1) strategi perbaikan sistem pemasaran dan tata kelola ternak; (2) strategi penguatan permodalan; (3) strategi penerapan kawasan peternakan terpadu; dan (4) strategi pembangunan sarana prasarana pendukung peternakan.

Saran-saran yang dapat disampaikan terkait dengan implementasi kesimpulan di atas adalah sebagai berikut.

1. Kepada pemerintah dalam hal ini Dinas Sosial untuk lebih meningkatkan pembinaan dan pengawasan secara konsisten dengan berkolaborasi dengan semua pihak yang terkait dalam penyelenggaraan program pemberdayaan, baik dengan tenaga pusat, provinsi, kabupaten, kecamatan, kelurahan, warga tokoh masyarakat dan pengelola KUBE. Kepada Dinas Peternakan supaya lebih meningkatkan intensitas penyuluhan pengenalan teknologi tepat guna peternakan yang ramah lingkungan. Selanjutnya kepada aparat Kelurahan Tampang Tumbang Anjir supaya dapat berperan memantau dan mengawasi dengan membentuk kelompok pengawas yang disepakati oleh warga yang tugasnya mengontrol perkembangan usaha ternak sapi pada KUBE 'Sama Handi'.

2. Untuk peningkatan usaha ekonomi produktif KUBE Fakir Miskin 'Sama Handi' di Kecamatan Kurun, kedepannya agar lebih diarahkan lagi keusaha bisnis peternakan (agribisnis) yang ramah lingkungan, khususnya dalam pola pemeliharaan sapi, pengolahan pakan, pengolahan limbah, sebagai upaya mempercepat pengentasan kemiskinan dan turut menjaga upaya pelestarian sumberdaya alam lingkungan.

3. Kepada anggota dan pengurus KUBE 'Sama Handi' di Kecamatan Kurun, hendaknya bisa lebih meningkatkan motivasi semangat kebersamaan, berkreasi, berinovasi menambah pengetahuan, wawasan, kemampuan, pola pikir dan dapat menjalin kemitraan dengan pihak terkait.

4. Sebagai pelaksana pendampingan dapat ditunjuk fasilitator dari unit kerja yang membidangi pemberdayaan fakir miskin dengan melibatkan pemerintah, supaya mempermudah koordinasi dengan tenaga penyuluh teknis dari instansi/ dinas/ lembaga lain yang juga bergerak dalam bidang pemberdayaan masyarakat.

5. Bagi peneliti lain, untuk kemajuan KUBE 'Sama Handi' yang berkelanjutan sebagai kawasan agribisnis sentra lumbung peternakan sapi, maka diperlukan penelitain lebih lanjut terkait tata kelola pemanfaatan lahan bekas tambang, pengelolaan dan pemanfaatan limbah peternakan yang ramah lingkungan.

\section{DAFTAR PUSTAKA}

Afifuddin, B. A. S., \& Saebani, B. A. (2012). Metodologi Penelitian Kualitatif. Bandung: Pustaka Setia.

Badan Pusat Statistik Kabupaten Gunung Mas. (2019). Gunung Mas Dalam Angka. Gunung Mas: BPS.

Badan Pusat Statistik (2019). Profil Kemiskinan di Indonesia Maret 2019. Jakarta: BPS.

Kementerian Sosial (2018). Kelompok Usaha Bersama. Jakarta: Direktorat Jenderal Penanganan Fakir Miskin.

Prastowo, A. (2011). Metode Penelitian Kualitatif Dalam Prespektif Rancangan Penelitian. Yogyakarta: Ar-Ruzz Media. 